\title{
Factors influencing the dissolved iron input by river water to the open ocean
}

\author{
R. Krachler, F. Jirsa, and S. Ayromlou \\ A1090 Vienna, Austria \\ Received: 22 March 2005 - Published in Biogeosciences Discussions: 9 May 2005 \\ Revised: 7 October 2005 - Accepted: 31 October 2005 - Published: 7 November 2005
}

Institute of Inorganic Chemistry - Bioinorganic, Environmental and Radiochemistry, Vienna University, Waehringerstraße 42,

\begin{abstract}
The influence of natural metal chelators on the bio-available iron input to the ocean by river water was studied. Ferrous and ferric ions present as suspended colloidal particles maintaining the semblance of a dissolved load are coagulated and settled as their freshwater carrier is mixed with seawater at the continental boundary. However, we might argue that different iron-binding colloids become sequentially destabilized in meeting progressively increasing salinities. By use of a ${ }^{59} \mathrm{Fe}$ tracer method, the partitioning of the iron load from the suspended and dissolved mobile fraction to storage in the sediments was measured with high accuracy in mixtures of natural river water with artificial sea water. The results show a characteristic sequence of sedimentation. Various colloids of different stability are removed from a water of increasing salinity, such as it is the case in the transition from a river water to the open sea. However, the iron transport capacities of the investigated river waters differed greatly. A mountainous river in the Austrian Alps would add only about $5 \%$ of its dissolved Fe load, that is about $2.0 \mu \mathrm{g} \mathrm{L}^{-1} \mathrm{Fe}$, to coastal waters. A small tributary draining a sphagnum peat-bog, which acts as a source of refractory low-molecular-weight fulvic acids to the river water, would add approximately $20 \%$ of its original Fe load, that is up to $480 \mu \mathrm{g} \mathrm{L}^{-1} \mathrm{Fe}$ to the ocean's bio-available iron pool. This points to a natural mechanism of ocean iron fertilization by terrigenous fulvic-iron complexes originating from weathering processes occurring in the soils upstream.
\end{abstract}

Correspondence to: R. Krachler

(regina.krachler@univie.ac.at)

\section{Introduction}

It is widely accepted that dissolved organic matter (DOM) represents a dynamic component in the interaction between geosphere, biosphere and hydrosphere, and as such has the potential to influence the global carbon cycle and climatic change. The aim of the present work was to study the influence of natural organic metal chelators on the bio-available iron input to the ocean by river water.

Uptake of $\mathrm{CO}_{2}$ in the ocean due to phytoplankton photosynthesis is generally followed by a zooplankton bloom as grazers respond to the increased food supply. These populations then produce marine snow, as fecal pellets and other particles descend through the water column, exporting their carbon load to water masses beyond the mixing zone, a process known as the "marine biological carbon pump". This export of organic carbon from the surface to the ocean interior accounts for 11 to $16 \mathrm{PgCy}^{-1}$ (Falkowski et al., 2000). However, since the early 1980s, global ocean phytoplankton concentrations have declined substantially, i.e. more than $6 \%$. This suggests major implications for the global carbon cycle (Gregg et al., 2003).

In many regions of the ocean carbon uptake during plankton photosynthesis is limited not by light nor by major nutrients, but by a lack of the trace metal iron. The dissolved iron concentrations are very low $(0.02-0.5 \mathrm{nmol} / \mathrm{L})($ Buesseler et al., 2003).

One of the ocean's natural iron sources is continental weathering of silicate rocks and, subsequently, river input of dissolved weathering products. However, the river-borne iron input to the open ocean is controlled by sedimentation processes. During estuarine mixing, the particulate and dissolved inorganic and organic colloids $>10000$ relative molar mass flocculate due to the major change in $\mathrm{pH}$ and ionic strength (Dai and Martin, 1995). The global river input

(C) 2005 Author(s). This work is licensed under a Creative Commons License. 
Table 1. River water samples, in situ measurements.

\begin{tabular}{lccccc}
\hline Sample & Temperature $\left({ }^{\circ} \mathrm{C}\right)$ & $\mathrm{pH}$-value & $\begin{array}{c}\% \mathrm{O}_{2} \\
\text { saturation }\end{array}$ & $\begin{array}{c}\text { Specific electric } \\
\text { conductance } \\
\left(\mu \mathrm{S} \mathrm{cm}^{-1}\right)\end{array}$ & $\begin{array}{l}\text { Ecosystems as sources } \\
\text { of natural allochthonous } \\
\text { inputs; Geology }\end{array}$ \\
\hline $\begin{array}{l}\text { River Schwarza: } \\
\text { Alpine river }\end{array}$ & $2.2 \pm 0.1$ & $8.30 \pm 0.05$ & 103 & $840 \pm 20$ & $\begin{array}{l}\text { Alpine spruce forests; } \\
\text { limestone area }\end{array}$ \\
$\begin{array}{l}15^{\circ} 46^{\prime} \mathrm{E}, 47^{\circ} 45^{\prime} \mathrm{N} \\
\text { Tannermoor brook: }\end{array}$ & $1.6 \pm 0.1$ & $5.70 \pm 0.05$ & 98 & $50 \pm 4$ & $\begin{array}{l}\text { Sphagnum peat-bog; } \\
\text { silicate rocks }\end{array}$ \\
$\begin{array}{l}\text { Small tributary stream } \\
14^{\circ} 52^{\prime} \mathrm{E}, 48^{\circ} 30^{\prime} \mathrm{N}\end{array}$ & & & & \\
\hline
\end{tabular}

of bio-available iron to the ocean has therefore been estimated to be only of marginal importance (de Baar and de Jong, 2001). However, it has been found recently that, in the Mississippi River plume, certain organic complexes between $\mathrm{Fe}^{3+}$ and terrestrially derived organic material escape the estuarine mixing zone and contribute essentially to the fertility of the coastal waters (Rose and Waite, 2003; Powell and Wilson-Finelli, 2003).

This suggests that the iron transport capacity of a river is closely related to the vegetation types in its watershed, as soils are the source of both, dissolved iron as well as dissolved organic matter to the river water.

Dissolved organic matter (DOM) in aquatic environments represents one of the largest active carbon reservoirs in the biosphere (Amon and Benner, 1996). Aquatic fulvic acids are a major fraction of DOM in natural waters and account for $50-80 \%$ of the total amount of dissolved organic carbon.

Aquatic fulvic acids derived from terrestrial precursor organic material - plant litter and soils - generally contain significant content of aromatic carbon (25-30\% of total carbon), reflecting the contribution of lignin degradation to their formation (Malcom, 1990; McKnight et al., 1994; Yamada et al., 2000). Large macromolecules are rapidly utilized by the streambed microbial community, while the $<10000$ relative molecular weight fulvic acids are biologically less reactive and can escape microbial utilization. Further degradation mainly due to photochemical processes leads eventually to oxidation, however, fulvic acids exhibit a half-life of several weeks in aquatic environments. Among these compounds, we find strong metal chelators which could serve as vehicles for the transport of bio-available iron in rivers and estuaries.

Although structure and chemical properties of fulvic acids have been studied extensively, little is known about their functioning as transport vehicles for essential trace metals in the continental runoff. In the present work, a ${ }^{59} \mathrm{Fe}$ tracer method was used to investigate the partitioning of the river's iron load from the suspended and dissolved mobile fraction to storage in the sediments as a function of salinity. The aim was to compare two different unpolluted low-order streams which contribute to the iron-transport behaviour of a large river.
We are aware of the possible transformation and removal of fulvic acids during their travel from peatland bog through small rivers, reservoirs and large rivers to the estuaries. However, catchments with high proportions of peatland have been found to be linked to enhanced peat-derived DOM concentrations in rivers. The relationship between stream water DOM concentrations and catchment soil $\mathrm{C}$ pools exists in both the small- and large-scale catchments (Aitkenhead 1999; Elder 2000).

\section{Materials and methods}

\subsection{Study sites}

Two unpolluted study sites in the catchment basin of River Danube were chosen to represent different ecosystems acting both as source of DOM and dissolved iron to the river water. In Table 1 a short description of the sampling sites and characteristics of the waters collected is given.

Tannermoor $\left(14^{\circ} 52^{\prime} \mathrm{E}, 48^{\circ} 30^{\prime} \mathrm{N}\right)$ situated in north eastern part of Upper Austria Muehlviertel is one of Austria's largest remnant peat-bogs covering an area of approximately $1 \mathrm{~km}^{2}$. Tannermoor brook is draining the peat-bog and absolutely unpolluted.

River Schwarza $\left(15^{\circ} 46^{\prime} \mathrm{E}, 47^{\circ} 45^{\prime} \mathrm{N}\right)$ is draining headwaters area for Vienna drinking water supply and hence unpolluted to a high degree as well.

\subsection{Sampling and experimental procedures}

Sampling was conducted under meteorological and hydrological conditions of the winter months, i.e. low water levels and air temperatures between $-6^{\circ} \mathrm{C}$ and $0^{\circ} \mathrm{C}$. Samples (ca. $5 \mathrm{~L}$ ) were taken with a clean polyethylene bucket from the surface. The samples were collected in the evening, transported in clean polyethylene bottles to the laboratory, stored in a refrigerator, and processed within a few hours.

The initial water samples were passed through a $0.22 \mu \mathrm{m}$ GV Durapore membrane by vacuum filtration to remove particulate material, eukaryotes and bacteria. DOC (dissolved 
Table 2. Experimental results of filtrates from river water samples.

\begin{tabular}{lccl}
\hline Sample & $\begin{array}{c}\mathrm{Fe}(\mathrm{II})+\mathrm{Fe}(\mathrm{III}) \\
\left(\mu \mathrm{g} \cdot \mathrm{L}^{-1}\right) \pm 5 \%\end{array}$ & $\begin{array}{c}\mathrm{DOC} \\
(\mathrm{ppm}) \pm 10 \%\end{array}$ & $\begin{array}{l}\mathrm{r}\left(\mu \mathrm{g} \cdot \mathrm{L}^{-1}\right) \text { river input of bio-available iron to } \\
\text { the open sea, as resulting from the present } \\
\text { model experiments }\end{array}$ \\
\hline $\begin{array}{l}\text { River Schwarza } \\
\text { Tannermoor brook }\end{array}$ & $\begin{array}{c}40 \\
2400\end{array}$ & 1.09 & $\begin{array}{l}2 \\
16.00\end{array}$ \\
\hline
\end{tabular}

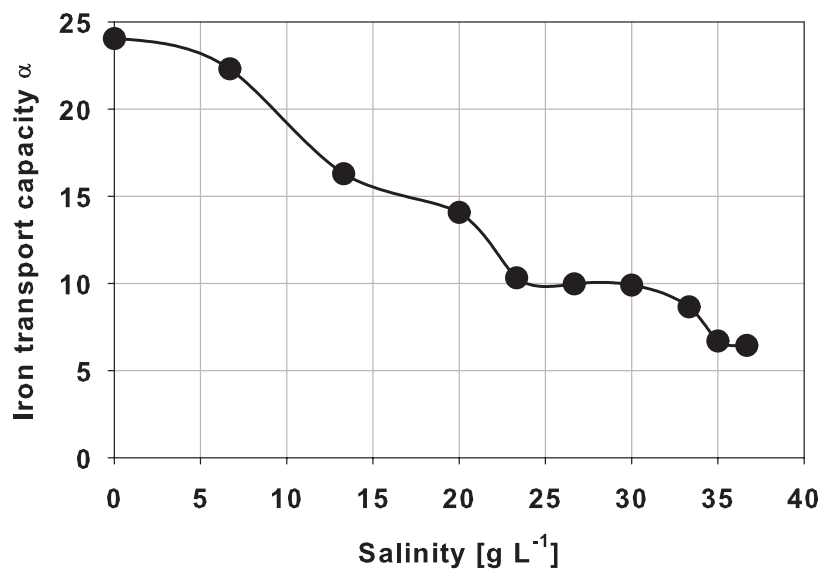

Fig. 1. Iron transport capacity $\alpha$ (experimental data and spline curve) of River Schwarza (Lower Austria) as a function of salinity, determined by use of a ${ }^{59} \mathrm{Fe}$ tracer method. $\alpha$ is the fraction of dissolved iron and initially dissolved iron $\alpha=\frac{\mathrm{Fe} \text { (dissolved) } * 100}{\mathrm{Fe} \text { (initially dissolved) }}$ present in a mixture of air-saturated natural river water and artificial coastal water after $100 \mathrm{~h}$ reaction duration at approximately $8^{\circ} \mathrm{C}$. Mixing method: shaking. The estimated error bars are $\pm 3 \%$.

organic carbon) concentrations were determined in the filtrates using a wet oxidation TOC analyser. $100 \mathrm{~mL}$ samples of the filtrates were acidified with concentrated nitric acid to a pH of approximately 1.8 and stored in polyethylene bottles in a refrigerator prior to the analysis of initially dissolved iron, using flame-AAS. DOC and iron concentrations in the filtered river water samples are shown in Table 2.

A ${ }^{59} \mathrm{Fe}$ radionuclide tracer $\left(\mathrm{FeCl}_{2}\right.$ in $0.1 \mathrm{~N} \mathrm{HCl}$ from NENPerkinElmer) was added to $10 \mathrm{~mL}$ filtered river water samples in clean $80 \mathrm{~mL}$ polyethylene tubes. Additional $\mathrm{Fe}$ concentrations in all treatments due to the addition of the ${ }^{59} \mathrm{Fe}$ tracer were estimated to be $<0.1 \%$. A Ge-Detector was used for counting the gamma rays of ${ }^{59} \mathrm{Fe}(1099 \mathrm{keV}, 1291 \mathrm{keV})$. Detection times were about $20 \mathrm{~min}$.

Subsequently, the samples were mixed with $50 \mathrm{~mL}$ artificial coastal water with salinities between 0 and $42 \mathrm{~g} \cdot \mathrm{L}^{-1}$. The artificial seawater $\left(\mathrm{pH}=8.2\right.$, salinity $\left.=42 \mathrm{~g} \cdot \mathrm{L}^{-1}\right)$ was free of organic material. The composition of the artificial sea salt was (mass fraction given in \%): $\mathrm{Cl}^{-}$(55.04), $\mathrm{SO}_{4}^{2-}$ (7.68), $\mathrm{HCO}_{3}^{-}$(0.41), $\mathrm{Br}^{-}$(0.19), $\mathrm{H}_{3} \mathrm{BO}_{3}(0.07), \mathrm{Na}^{+}$(30.61),

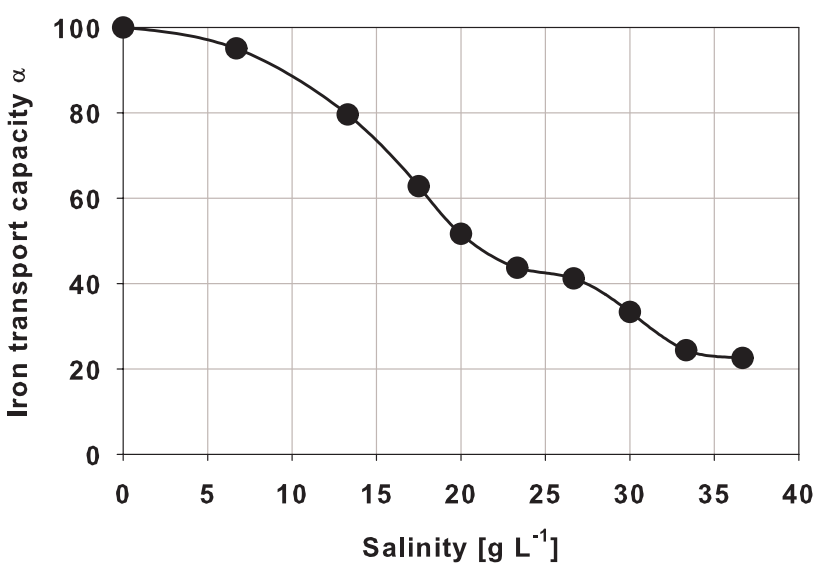

Fig. 2. Iron transport capacity $\alpha$ (experimental data and spline curve) of the Tannermoor brook (Lower Austria) as a function of salinity, determined by use of a ${ }^{59}$ Fe tracer method. $\alpha$ is the fraction of dissolved iron and initially dissolved iron $\alpha=\frac{\mathrm{Fe} \text { (dissolved) } * 100}{\mathrm{Fe}(\text { initially dissolved })}$ present in a mixture of air-saturated natural river water and artificial coastal water after $100 \mathrm{~h}$ reaction duration at approximately $8^{\circ} \mathrm{C}$. Mixing method: shaking. The estimated error bars are $\pm 3 \%$.

$\mathrm{Mg}^{2+}$ (3.69), $\mathrm{Ca}^{2+}$ (1.16), $\mathrm{K}^{+}$(1.10), $\mathrm{Sr}^{2+}$ (0.04). The "coastal water" was prepared by mixing the artificial seawater with distilled water. The open tubes were placed on a shaker and shook for $12 \mathrm{~h}$, thereafter the air-saturated samples were stored in a refrigerator at $8^{\circ} \mathrm{C}$, and precipitation reactions were allowed to proceed for 4 days. After that time span, we assumed that isotopic equilibrium with respect to Fe was established. The tubes were centrifuged for $4 \mathrm{~h}$ at $6000 \mathrm{rpm}$ in order to separate the "water column" from the solid phase. From each tube, a $10 \mathrm{~mL}$ "water column" sample was pipetted into a clean polyethylene tube of identical geometry and the gamma rays of ${ }^{59} \mathrm{Fe}$ were counted.

\section{Results}

Results are shown in Figs. 1-2. The iron transport capacity $\alpha$ of the river water is defined as the ratio of the dissolved gamma-activity concentrations after and before precipitation due to the above described mixing with artificial coastal waters. Assuming isotopic equilibrium, $\alpha$ is the fraction of 
dissolved iron still present in air-saturated coastal surface waters of different salinities after $100 \mathrm{~h}$ at approximately $8^{\circ} \mathrm{C}$ :

$\alpha=\frac{\text { Fe(dissolved) }}{\text { Fe(initially dissolved })}$

The estimated error bars of analysis of iron concentration are $\pm 3 \%$.

From the $\alpha$ versus salinity curves we can see that different iron-binding inorganic or organic colloids become sequentially destabilized in meeting progressively increasing salinities such as it is the case in the transition from a river water to the open sea. In Fig. 1 (River Schwarza), the experimental curve seems to have three inflection points. Accordingly, four different fractions of colloids exhibiting different stabilities are removed from a water of changing composition. The experimental curve in Fig. 2 (Tannermoor brook) shows two inflection points. At least three different fractions of colloids are removed from the water column, and we find extremely high $\alpha$ values over the whole concentration range.

Using the initial iron concentration $c_{i}$ found in the filtered river water sample a few hours after collecting the sample (see Table 2), and the value of $\alpha$ at $35 \mathrm{~g} \cdot \mathrm{L}^{-1}$ salinity $\alpha_{35}$ (presented in Figs. 1-2), we can calculate the river input $r$ of bio-available iron to the open sea, according to the present model experiments:

$r\left(\mathrm{mg} \cdot \mathrm{L}^{-1}\right)=\frac{\alpha_{35}(\%) \times c_{i}\left(\mathrm{mg} \cdot \mathrm{L}^{-1}\right)}{100}$

The resulting $\mathrm{r}$ values are shown in Table 2 .

\section{Discussion}

Due to the very low solubility of the inorganic Fe(III) species in natural waters, the river iron input to the ocean is mainly determined by the presence and concentration of low molecular weight colloidal fulvic-iron complexes in the river water which are interpreted as originating from processes occurring in the soils upstream. Since these compounds are derived from terrestrial precursor materials - plant litter and soils - their concentrations and chemical characteristics depend strongly on the types of terrestrial vegetation in the river's catchment basin.

Dai and Martin (1995) found in the $\mathrm{Ob}$ and Yenisey rivers flocculation and sedimentation of more than $90 \%$ of the dissolved organic material and the complexed iron, respectively, and only $36-44 \mathrm{nmol} \cdot \mathrm{L}^{-1}$ iron escaped the estuarine mixing zone. Iron transport capacities similar to those of the $\mathrm{Ob}$ and Yenisey rivers have been found worldwide in many other river waters.

According to our experimental results, the Alpine river Schwarza is such a common river, which would be characterized by flocculation and sedimentation of $95 \%$ of the dissolved iron, with only $35.7 \mathrm{nmol} \cdot \mathrm{L}^{-1}$ iron escaping the estuarine mixing zone. In contrast, the Tannermoor brook shows an extraordinary high iron transport capacity. This river water is rich in dissolved iron and fulvic acids originating from a sphagnum peat-bog. Very likely due to complexation with these organic ligands, the concentration of iron remains above the iron-hydroxide solubility level until a salinity above 35 is reached. The Tannermoor brook would add approximately $20 \%$ of its $\mathrm{Fe}$ load, that is $8570 \mathrm{nmol} \cdot \mathrm{L}^{-1} \mathrm{Fe}$ to the ocean's dissolved iron pool.

The solubility of Fe(III)-hydroxide in oceanic water has been determined by Kuma et al. (1996). These measurements indicate a total dissolved inorganic $\mathrm{Fe}(\mathrm{III})$ concentration on the order of $0.1 \mathrm{nmol} \cdot \mathrm{L}^{-1}$. Fe(III) species dominate in oxic seawater with very low equilibrium concentrations of $\mathrm{Fe}(\mathrm{II})$ species. Our results indicate that the solubility of organically complexed iron derived from peat-bog in oxic seawater is at least four orders of magnitude higher than the solubility of iron-hydroxide.

The magnitudes of the various sources and sinks in the iron cycle are not well known. Estimates of these terms have been presented by de Baar and de Jong (2001). The wordwide discharge of river water is about $37 \times 10^{12} \mathrm{~m}^{3} \mathrm{y}^{-1}$. Dai and Martin (1995) found an average dissolved iron concentration in river waters of $40 \mathrm{nmol} \mathrm{L}^{-1}$. This value, applied globally, would give an dissolved $\mathrm{Fe}$ input to the ocean of only $1.5 \times 10^{9} \mathrm{~mol} \mathrm{y}^{-1}$.

According to the present results, rivers draining sphagnum peatlands on silicate rocks contribute dissolved $\mathrm{Fe}$ concentrations of more than $8000 \mathrm{nmol} \mathrm{L}^{-1}$. The area of sphagnum peatlands in North America, Europe and Asia is approximately $19 \times 10^{6} \mathrm{~km}^{2}$ (Gajewski et al., 2001), i.e. sphagnum peatlands cover $14 \%$ of the global land surface. Assuming that $5 \%$ of the global discharge of river water is true "peatland runoff", the dissolved iron input to the ocean's surface waters is around $15 \times 10^{9} \mathrm{~mol} \mathrm{y}^{-1}$. This points to a very important natural mechanism of ocean iron fertilization by river-borne fulvic-iron complexes.

Edited by: N. Caraco

\section{References}

Aitkenhead, J. A., Hope, D., and Billet, M. F.: The relationship between dissolved organic carbon in stream water and soil organic carbon pools at different spatial scales, Hydrol. Processes, 123 (8), 1289-1302, 1999.

Amon, R. M. W. and Benner, R.: Bacterial utilization of different size classes of dissolved organic matter, Limnol. Oceanogr., 4(1), 41-51, 1996.

Buesseler, K. O. and Boyd, P. W.: Will ocean fertilization work? Science, 300 (5616), 67-68, 2003.

Dai, M. and Martin, J. M.: First data on trace metal level and behaviour in two major Arctic river-estuarine systems ( $\mathrm{Ob}$ and Yenisey) and in the adjacent Kara Sea, Earth Planet. Sci. Lett., 131, 127-141, 1995.

De Baar, H. J. W. and De Jong, J. T. M.: Distributions, sources and sinks of iron in seawater, in: The Biogeochemistry of Iron in Seawater, edited by: Buffle, J. and van Leeuwen, H. P., Vol. 7, 
IUPAC Series on Analytical and Physical Chemistry of Environmental Systems, 2001.

Elder, J. F., Rybicki, N. B., Carter, V., and Weintraub, V.: Sources and yields of dissolved carbon in northern Wisconsin stream catchments with different amounts of peatland, Wetlands, 20(1), $113-125,2000$

Falkowski, P., Scholes, R. W., Boyle, E., et al.: The Global Carbon Cycle: A Test of Our Knowledge of Earth as a System, Science, 290, 5490, 291-296, 2000.

Gajewski, K., Viau, A., Sawada, M., Atkinson, D., and Wilson, S.: Sphagnum peatland distribution in North America and Eurasia during the past 21000 years, Global Biogeochem. Cycles, 15 (2), 297-310, 2001.

Gregg, W. W., Conkright, M. E., Ginoux, P., O'Reilly, J. E., and Casey, N. W.: Ocean primary production and climate: Global decadal changes, Geophys. Res. Lett., 30(15), 1809, doi:10.1029/2003GL016889, 2003.

Kuma, K., Nishioka, J., and Matsunaga, K.: Controls on iron(III)hydroxide solubility in seawater: the influence of $\mathrm{pH}$ and natural organic chelators, Limnol. Oceanogr., 41, 396-407, 1996.
Linnik, P. N.: Complexation as the most important factor in the fate and transport of heavy metals in the Dnieper water bodies, Anal. Bioanal. Chem., 376 (3), 405-412, 2003.

McKnight, D. M., Andrews, E. D., Spaulding, S. A., and Aiken, G. R.: Aquatic fulvic acids in algal-rich Antarctic ponds, Limnol. Oceanogr., 39, 1972-1979, 1994.

Malcom, R.: The uniqueness of humic substances in each of soil, stream, and marine environments, Anal. Chim. Acta, 232, 19-30, 1990.

Powell, R. T. and Wilson-Finelli, A.: Importance of organic $\mathrm{Fe}$ complexing ligands in the Mississippi River plume, Estuarine Coastal and Shelf Science, 58 (4), 757-763, 2003.

Rose, A. L. and Waite, T. D.: Kinetics of iron complexation by dissolved natural organic matter in coastal waters, Mar. Chem., 84 (1-2), 85-203, 2003.

Yamada, E., Doi, K., Okano, K., and Fuse, Y.: Simultaneous Determinations of the Concentration and Molecular Weight of Humic Substances in Environmental Water by Gel Chromatography with a Fluorescence Detector, Anal. Sci., 16, 125-129, 2000. 